\title{
Chondroid syringoma: an unusual presentation in a 7-year-old boy
}

\author{
Pujon Purkayastha 당 , Richard Thomson, Nicholas Wilson Jones, Selwyn Ng
}

Plastic Surgery Department, Swansea Bay University Health Board, Port Talbot, UK

\section{Correspondence to} Dr Pujon Purkayastha; dr.purkayastha@doctors.org.uk

Accepted 22 May 2021

\section{SUMMARY}

Coined in 1961 by Hirsch and Helwig, the term chondroid syringoma refers to a rare mixed tumour of subcutaneous tissue. Histologically, these tumours are almost identical to pleomorphic adenomas, arising from salivary glands. With the obvious difference being the presence of sweat gland tissue (syringoma) within a matrix of cartilage (chondroid). These mixed tumours remain scarce throughout the world, with an incidence of less than $0.098 \%$. The vast majority of cases are reported in middle-aged and older adults, where they typically present as painless swellings in the head and neck, which gradually grow in size.

\section{BACKGROUND}

This case is unique because not only was the chondroid syringoma (CS) found in a 7-year-old child, but it presented as a rapidly growing swelling which tripled in size over a 4-month time period. We hope that by presenting this atypical case, CS remains a differential diagnosis for patients of all age groups, who present with a painless swelling.

\section{CASE PRESENTATION}

A 7-year-old boy was referred from his community paediatric services with a rapidly growing lesion that had tripled in size over a short duration of 4 months, and interfered with him wearing his glasses. The patient was urgently reviewed by the paediatric plastic surgery team and subsequently discussed with paediatric oncology, with the concern that the lesion may represent a malignancy. On examination, a $2 \times 2 \mathrm{~cm}$ firm lesion was found in the left cheek. It had a blue discolouration with a surrounding area of hypervascularity (figure 1). An MRI scan (figure 2) showed a well-defined mass, involving cutaneous

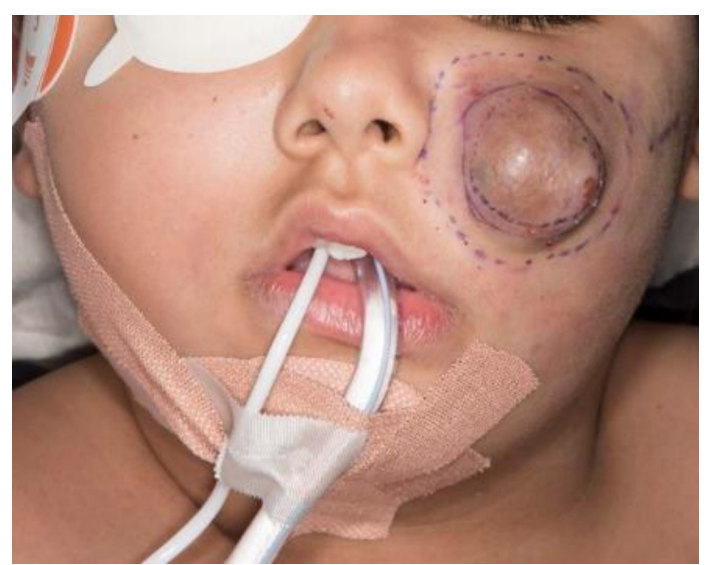

Figure 1 Intraoperative image.

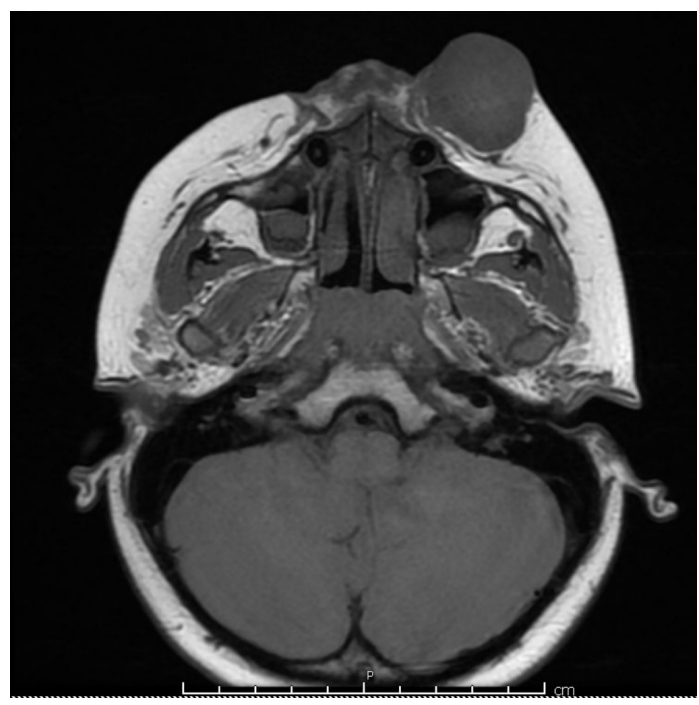

Figure 2 Preoperative MRI.

and subcutaneous tissues, which were separate from the parotid gland and underlying musculature. An ultrasound-guided core biopsy enabled examination of the histological features required to make the diagnosis of a CS (figure 3).

Under general anaesthetic, the left cheek was widely infiltrated with $0.25 \%$ bupivacaine+epinephrine (1:200 000). Via a circumferential incision, the lesion was excised with a $5 \mathrm{~mm}$ peripheral margin with a $5 \mathrm{~mm}$ cuff of subcutaneous fat. The skin was closed respecting the lines of election with 5-0 Monocryl (deep dermal) and a 5-0 vicryl rapide (continuous subcuticular). The excised specimen was $3 \times 3 \times 3 \mathrm{~cm}$ in size, and was sent for histological analysis, which confirmed the diagnosis of a CS. The lesion was well circumscribed with no infiltrative growth into surrounding tissues. There was no evidence of cellular atypia, increased mitoses or perineural invasion and no lymphovascular invasion was seen.

\section{OUTCOME AND FOLLOW-UP}

The surgical scar healed well (figure 4) and a follow-up ultrasound scan in 6 months displayed no evidence of tumour recurrence. The patient will attend clinic every 3 months for clinical review and also undergo ultrasound surveillance every 6 months.

\section{DISCUSSION}

CS is a benign neoplasm which is derived from sweat glands, and it typically presents as a painless subcutaneous nodule found in older and middle-aged 


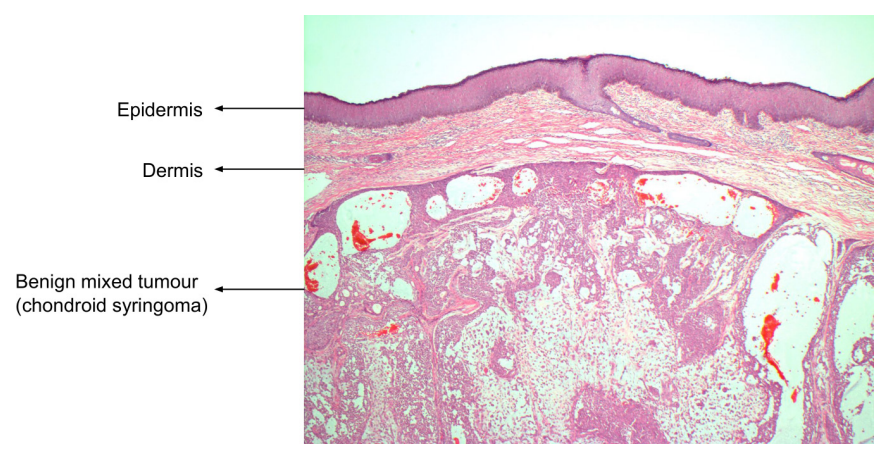

Figure 3 Histology slide confirming the presence of a chondroid syringoma.

adults. ${ }^{12}$ With an annual incidence of less than $0.098 \%,{ }^{3}$ CS remains a rare diagnosis which can only be confirmed after histological analysis. The condition is even less likely to be found in a child, with the first case not being reported until $2007 .{ }^{4}$ In their study, Turhan-Haktanir et al reported on an 11-year-old boy, who presented with a mass on his right nasal ala, which had been gradually growing for a year. Their presumptive clinical diagnosis was a pilomatrixoma (a benign appendageal tumour of hair follicles), and it was not until the excised specimen was sent for histopathological analysis, that they could come to the diagnosis of a CS.

Amin et al published a case of CS which bears some clinical resemblance to our case. ${ }^{3}$ They reported on a benign CS in the cheek of a 50-year-old woman, which had gradually started to interfere with her vision. The stark difference between the cases is that their patient's CS tumour grew over a course of three decades, whereas our patient's tumour had tripled in size over a 4-month period to give similar issues with vision. Solanki et al report on a case of CS in a 21-year-old woman, who presented with a well defined $4 \times 3 \mathrm{~cm}$ lesion on her left cheek, which had gradually grown in size over 3 years. ${ }^{5}$

Recent studies are also reporting cases of malignant CS presenting in the facial region as a painless nodule. ${ }^{67}$ In their study, Chauvel-Picard et al highlight that to date only 12 cases of malignant CS have thus far been localised to the craniofacial region. The authors recommend wide local excision as the only effective treatment, with little data supporting the use of

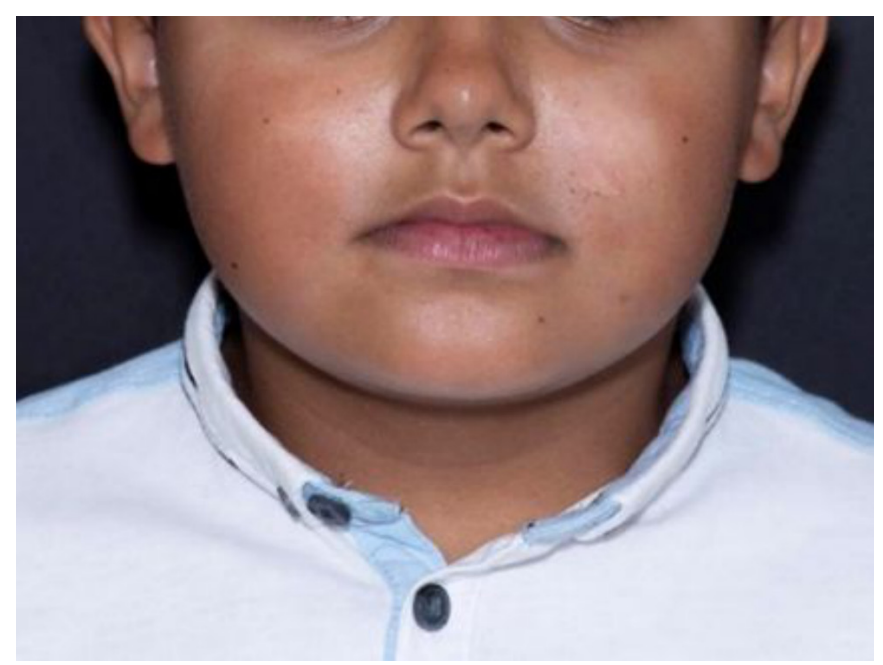

Figure 4 A 6-month postoperative image following excision and reconstruction. chemotherapy or radiation. ${ }^{6}$ It is worth bearing in mind that most cases of malignant CS usually present in the truncal region and extremities. ${ }^{7}$ Nevertheless, these recent case studies highlight the importance of maintaining diagnostic scepticism when faced with a growing lesion.

\section{Investigations and management of CS}

One of the main reasons CS are difficult to diagnose preoperatively is likely to reflect the lack of clinical characteristics which are specific to the diagnosis. ${ }^{8}$ As a result, more established and well recognised conditions (eg, a sebaceous cyst or haemangioma) are often considered beforehand. ${ }^{9}$ The most common misdiagnosis of CS is arguably pleomorphic adenomas, which are practically identical in appearance to CS. ${ }^{10}$ To aid in making a confident diagnosis of CS, the authors who coined the term 'CS' in 1961 also stipulated the histological criteria required to make a diagnosis of CS. As expected, one of these criteria is the presence of both chondroid and myxoid material within the matrix. ${ }^{11}$ In rare cases, CS may show signs of ossification under imaging, thus making diagnosis particularly difficult. ${ }^{1}$

Ultrasound remains a popular choice of imaging for soft-tissue masses in children, as it does not entail any exposure to radiation. MRI shares this benefit at a higher cost,${ }^{10}$ but does provide highly detailed images of the soft-tissues to aid diagnosis and surgical planning. Ultrasound-guided core biopsy was performed in this case on advice from the regional paediatric oncology unit and following the UK guidance on management of suspected primary soft-tissue sarcomas, ${ }^{12}$ in order to maximise diagnostic yield. It is worth noting however that fine-needle aspiration cytology (FNAC) can be used to establish the histological criteria required to make a diagnosis of CS. ${ }^{13}{ }^{14}$ This is a less invasive method of analysis, which should be carried out before excision of the lesion. ${ }^{15}$ FNAC may be less appropriate in children, who will likely require some form of sedation ${ }^{10}$ but is particularly useful in the management of recurrent or metastatic malignancies of the head and neck.

Surgical excision remains the most effective method of treatment for CS, as it ensures the entire tumour is removed at once. ${ }^{16}$ In order to reduce the risk of tumour recurrence, it is also recommended to remove a rim of normal tissue along with the tumour. ${ }^{17}$ Less invasive methods have been reported, which include electrodessication and dermabrasion, and even laser vaporisation. ${ }^{8}$ Despite the chosen method of CS treatment, it is usually recommended that patients are followed up regularly to detect any tumour recurrence. ${ }^{5}$

CS typically presents as a benign tumour, but in a minority of cases it can take a malignant form, where the tumour is characterised by local invasion and more rapid growth. ${ }^{18}$ The most devastating cases of malignant CS have been shown to display widespread metastases, and their location is not limited to the head and neck, but can be found throughout the body. ${ }^{18-20}$

\section{Learning points}

- In conclusion, we have presented an unusual case of chondroid syringoma found in the cheek of a 7-year-old boy.

- This case is notable not only due to the patient's age, but due to the rapid growth of the tumour, which tripled in size over a 4-month time period.

- We hope that this case will raise awareness of the potentially varied nature of chondroid syringoma in patients of all age groups. 
Malignant forms of CS will also have characteristic features on histopathological examination, which include a more pronounced presence of mitotic figures and tumour necrosis. ${ }^{18}$ In such cases, novel methods of comparative genomic hybridisation may be used to clarify the diagnosis. ${ }^{21}$ Some authors have even suggested that tumour surveillance is only required for malignant forms of CS, as their benign counterparts do not recur after surgical excision. ${ }^{42}$

Contributors PP: Primary and corresponding author, responsible for background research into topic and literature review. Involved in collection and analysis of findings, involved in writing discussion of case study. RT: Surgical registrar involved in operation, involved in writing case presentation, responsible for obtaining patient consent. NWJ: Plastic surgery consultant involved in operation, involved in writing case presentation and discussion. Responsible for patient follow-up. SN: Pathologist involved in case, responsible for analysing pathology slides and confirming diagnosis. Created histology slides used in figure 4.

Funding The authors have not declared a specific grant for this research from any funding agency in the public, commercial or not-for-profit sectors.

Competing interests None declared.

Patient consent for publication Parental/guardian consent obtained.

Provenance and peer review Not commissioned; externally peer reviewed.

\section{ORCID iD}

Pujon Purkayastha http://orcid.org/0000-0001-6711-2507

\section{REFERENCES}

1 Awasthi R, Harmse D, Courtney D, et al. Benign mixed tumour of the skin with extensive ossification and marrow formation: a case report. J Clin Pathol 2004;57:1329-30.

2 Park SH, Kang SG, Choi HJ. Chondroid syringoma of a cheek. J Craniofac Surg 2017:28:e480-1.

3 Amin D, Al-Gorashi A, Al-Habbab RY. Case report: chondroid syringoma of the cheek. EC Dental Science 2015:1:159-63.

4 Turhan-Haktanir N, Sahin O, Bukulmez A, et al. Chondroid syringoma in a child. Pediatr Dermatol 2007;24:505-7.

5 Solanki LS, Dhingra M, Bhalla M, et al. Chondroid syringoma: report of two cases in young patients. Dermatol Online J 2011;17:7.
6 Chauvel-Picard J, Pierrefeu A, Harou 0, et al. Unusual cystic lesion of the eyebrow: a case report of malignant chondroid syringoma. J Stomatol Oral Maxillofac Surg 2018;119:232-5.

7 Reddy PB, Nandini DB, Sreedevi R, et al. Benign chondroid syringoma affecting the upper lip: report of a rare case and review of literature. J Oral Maxillofac Pathol 2018:22:401.

8 Yavuzer R, Başterzi Y, Sari A, et al. Chondroid syringoma: a diagnosis more frequent than expected. Dermatol Surg 2003:29:179-81.

9 Bekerecioglu M, Tercan M, Karakok M. Benign chondroid syringoma: a confusing clinical diagnosis. Eur J Plast Surg 2002;25:316-8.

10 Rodriguez $\mathrm{KH}$, Vargas S, Robson C, et al. Pleomorphic adenoma of the parotid gland in children. Int J Pediatr Otorhinolaryngol 2007:71:1717-23.

11 Hirsch P, Helwig EB. Chondroid syringoma. mixed tumor of skin, salivary gland type. Arch Dermatol 1961;84:835-47.

12 Dangoor A, Seddon B, Gerrand C, et al. UK guidelines for the management of soft tissue sarcomas. Clin Sarcoma Res 2016:6:20.

13 Skoro M, Ostović KT, Cikara I, et al. Fine needle aspiration cytology of chondroid syringoma. Coll Antropol 2010;34:687-90.

14 Syed MA, Paudel U, Rajbhandari A, et al. Fine needle aspiration cytology as a preliminary diagnostic tool in chondroid syringoma: a case report and review. Clin Cosmet Investig Dermatol 2019;12:209-18.

15 Padma M, Bharat Rao N. Giant chondroid Syringoma-Case report of rare entity at unusual sites-cytohistological features. IOSR J Dent Med Sci 2015;14:1-3.

16 Schulhof Z, Anastassov GE, Lumerman H, et al. Giant benign chondroid syringoma of the cheek: case report and review of the literature. J Oral Maxillofac Surg 2007;65:1836-9.

17 Mittal HK, Bist SS, Harsh M. Atypical facial chondroid syringoma, a rare clinical entity: case report with review of literature. Indian J Otolaryngol Head Neck Surg 2020;72:274-7.

18 Barnett MD, Wallack MK, Zuretti A, et al. Recurrent malignant chondroid syringoma of the foot: a case report and review of the literature. Am J Clin Oncol 2000;23:227-32.

19 Ishimura E, Iwamoto H, Kobashi Y, et al. Malignant chondroid syringoma. Report of a case with widespread metastasis and review of pertinent literature. Cancer 1983;52:1966-73.

20 Takahashi H, Ishiko A, Kobayashi M, et al. Malignant chondroid syringoma with bone invasion: a case report and review of the literature. Am I Dermatopathol 2004;26:403-6.

21 Zia S, Shaw B, Chapman S, et al. An atypical chondroid syringoma with malignant degeneration: utility of comparative genomic hybridization in confirming the diagnosis. J Cutan Pathol 2021;48:775-80.

22 Stout AP, Gorman JG. Mixed tumors of the skin of the salivary gland type. Cancer 1959:12:537-43.

Copyright 2021 BMJ Publishing Group. All rights reserved. For permission to reuse any of this content visit https://www.bmj.com/company/products-services/rights-and-licensing/permissions/ BMJ Case Report Fellows may re-use this article for personal use and teaching without any further permission.

Become a Fellow of BMJ Case Reports today and you can:

- Submit as many cases as you like

- Enjoy fast sympathetic peer review and rapid publication of accepted articles

Access all the published articles

Re-use any of the published material for personal use and teaching without further permission

Customer Service

If you have any further queries about your subscription, please contact our customer services team on +44 (0) 2071111105 or via email at support@bmj.com.

Visit casereports.bmj.com for more articles like this and to become a Fellow 